\title{
Impact of RNA editing on functions of the serotonin 2C receptor in vivo
}

\section{Uade B. Olaghere da Silva', Michael V. Morabito', Clinton E. Canal ${ }^{1,2}$, David C. Airey ${ }^{1,2}$, Ronald B. Emeson 1,2,3,4 and Elaine Sanders-Bush ${ }^{1,2,3 *}$}

1 Center for Molecular Neuroscience, Vanderbilt University School of Medicine, Nashville, TN, USA

2 Department of Pharmacology, Vanderbilt University School of Medicine, Nashville, TN, USA

${ }^{3}$ Department of Psychiatry, Vanderbilt University School of Medicine, Nashville, TN, USA

${ }^{4}$ Department of Molecular Physiology and Biophysics, Vanderbilt University School of Medicine, Nashville, TN, USA

\section{Edited by:}

Umberto Spampinato

University of Bordeaux 2, France

Reviewed by:

Stella Dracheva,

Mount Sinai School of Medicine, USA

Claudia Schmauss,

Columbia University, USA

Michel Hamon, UPMC, France

${ }^{*}$ Correspondence:

Elaine Sanders-Bush,

Department of Pharmacology,

Vanderbilt University School of

Medicine, 7160 Medical Research

Building III, Nashville, TN 37232-8548,

USA.

e-mail: elaine.bush@vanderbilt.edu

Transcripts encoding $5-\mathrm{HT}_{2 \mathrm{C}}$ receptors are modified posttranscriptionally by RNA editing, generating up to 24 protein isoforms. In recombinant cells, the fully edited isoform, $5-\mathrm{HT}_{2 \mathrm{C}-\mathrm{VG} \mathrm{V}^{\prime}}$ exhibits blunted G-protein coupling and reduced constitutive activity. The present studies examine the signal transduction properties of $5-\mathrm{HT}_{2 \mathrm{C}-\mathrm{vG}}$ receptors in brain to determine the in vivo consequences of altered editing. Using mice solely expressing the $5-\mathrm{HT}_{2 \mathrm{C}-\mathrm{VGV}}$ receptor (VGV/Y), we demonstrate reduced G-protein coupling efficiency and high-affinity agonist binding of brain 5- $\mathrm{HT}_{2 \mathrm{C}-\mathrm{vGV}}$ receptors. However, enhanced behavioral sensitivity to a 5- $\mathrm{HT}_{2 \mathrm{C}}$ receptor agonist was also seen in mice expressing 5- $\mathrm{HT}_{2 \mathrm{c}-\mathrm{vgV}}$ receptors, an unexpected finding given the blunted G-protein coupling. In addition, mice expressing 5- $\mathrm{HT}_{2 \mathrm{C}-\mathrm{VGV}}$ receptors had greater sensitivity to a $5-\mathrm{HT}_{2 \mathrm{C}}$ inverse agonist/antagonist enhancement of dopamine turnover relative to wild-type mice. These behavioral and biochemical results are most likely explained by increases in $5-\mathrm{HT}_{2 \mathrm{C}}$ receptor binding sites in the brains of mice solely expressing 5- $\mathrm{HT}_{2 \mathrm{C}-\mathrm{VGV}}$ receptors. We conclude that $5-\mathrm{HT}_{2 \mathrm{C}-\mathrm{VGV}}$ receptor signaling in brain is blunted, but this deficiency is masked by a marked increase in $5-\mathrm{HT}_{2 C}$ receptor binding site density in mice solely expressing the VGV isoform. These findings suggest that RNA editing may regulate the density of $5-\mathrm{HT}_{2 \mathrm{C}}$ receptor binding sites in brain. We further caution that the pattern of $5-\mathrm{HT}_{2 \mathrm{C}}$ receptor $\mathrm{RNA}$ isoforms may not reflect the pattern of protein isoforms, and hence the inferred overall function of the receptor.

Keywords: serotonin, 5- $\mathrm{HT}_{2 \mathrm{C}^{\prime}}$ RNA editing, signal transduction, behavior, DA turnover, $5-\mathrm{HT}_{2 \mathrm{C}}$ inverse agonist, $5-\mathrm{HT}_{2 \mathrm{C}}$ agonist

\section{INTRODUCTION}

The serotonin $2 \mathrm{C}\left(5-\mathrm{HT}_{2 \mathrm{C}}\right)$ receptor modulates a number of neurophysiological functions including appetite, mood, sexual behavior, and locomotion (Buhot, 1997; Olivier et al., 1998; Giorgetti and Tecott, 2004; Millan, 2005), and is implicated in the etiology of psychiatric disorders such as depression, anxiety, anorexia-nervosa, and obsessive-compulsive disorder (Griebel, 1995; Delgado and Moreno, 1998; Berg et al., 2008; Flaisher-Grinberg et al., 2008). Consequently, the $5-\mathrm{HT}_{2 \mathrm{C}}$ receptor has received considerable attention as a target for pharmacological treatment of these conditions (Meltzer et al., 2003; Serretti et al., 2004; Millan, 2005; Halford et al., 2007; Morabito and Emeson, 2009).

A distinctive feature of the G-protein coupled 5- $\mathrm{HT}_{2 C}$ receptor is its ability to be modified posttranscriptionally by RNA editing (Burns et al., 1997). RNA editing is an enzymatic process that converts adenosine to inosine at five nucleotide positions in the 5th exon of the 5- $\mathrm{HT}_{2 \mathrm{C}}$ receptor RNA transcript, encoding the second intracellular loop, a region important for G-protein coupling. Selective RNA editing can generate up to 32 mRNA isoforms, predicting 24 protein isoforms of the $5-\mathrm{HT}_{2 \mathrm{C}}$ receptor, potentially

Abbreviations: 5-HT, serotonin; DA, dopamine; [ $\left.{ }^{125} \mathrm{I}\right] \mathrm{DOI},( \pm)-1-(2,5,-$ dimethoxy-4-[125] iodophenyl)-2-aminopropane; INI, isoleucine-asparagine-isoleucine; MK212, 6-Chloro-2-(1-piperazinyl) pyrazine hydrochloride; PLC, phospholipase C; VGV, valine-glycine-valine; WT, wild-type. adding immense diversity to the function of the receptor in vivo. Furthermore, recent studies using animal models suggest that RNA editing of the $5-\mathrm{HT}_{2 \mathrm{C}}$ receptor is a dynamic process. For example, chronic stress increases the degree of RNA editing of the $5-\mathrm{HT}_{2 \mathrm{C}}$ receptor in both mice (Englander et al., 2005) and rats (Iwamoto et al., 2005). Variation in 5- $\mathrm{HT}_{2 \mathrm{C}}$ receptor RNA editing has also been implicated in a variety of neuropsychiatric disorders, with the most reproducible finding being an increase in RNA editing in brains of suicide victims (Niswender et al., 2001; Gurevich et al., 2002; Dracheva et al., 2008a,b). Despite these findings, defining the in vivo functional consequences of $5-\mathrm{HT}_{2 \mathrm{C}}$ receptor RNA editing has been limited due to technical constraints presented by the immense diversity of receptor RNA isoforms in brain.

In vitro studies in cultured cells transfected with cDNA encoding a single receptor isoform show that differentially edited $5-\mathrm{HT}_{2 \mathrm{C}}$ receptor isoforms have unique signaling features, with increased editing generally leading to decreased function. For example, the edited isoform valine-serine-valine (at amino acid positions 157, 159, 161 in humans) has four-fold reduced constitutive activity and four- to five-fold reduced serotonin potency to activate phospholipase C (PLC) relative to the non-edited isoleucineasparagine-isoleucine isoform (INI); the function of the fully edited valine-glycine-valine (VGV) isoform is reduced even further (Fitzgerald et al., 1999; Herrick-Davis et al., 1999; Niswender et al., 
1999). These studies suggest dramatic alterations will accompany changes in RNA editing of the $5-\mathrm{HT}_{2 \mathrm{C}}$ receptor; however, it is widely accepted that functional properties demonstrated in cell culture studies of cloned receptors may not be reproduced in vivo.

Since the majority of 5- $\mathrm{HT}_{2 \mathrm{C}}$ receptors in brain are edited (Burns et al., 1997), studies of the in vivo functional consequences of 5$\mathrm{HT}_{2 \mathrm{C}}$ receptor RNA editing are critically needed. Here we take advantage of mutant mice solely expressing a single isoform, the fully-edited 5- $\mathrm{HT}_{2 \mathrm{C}-\mathrm{VGV}}$ receptor, to characterize for the first time the signal transduction consequences of RNA editing of the $5-\mathrm{HT}_{2 \mathrm{C}}$ receptor in vivo. We show that the proximal event in cell signaling, receptor:G-protein coupling, is nearly abolished for the fully edited $5-\mathrm{HT}_{2 \mathrm{C}-\mathrm{VGV}}$ receptor in brain. We further show that changes in the degree of editing significantly alters the density of receptor binding sites within the brain, suggesting that the pattern of protein isoforms, and hence the inferred overall function of the receptor protein, may not reflect the pattern of RNA isoforms. This finding has significant ramifications for basic as well as clinical studies of disease-related alterations in RNA editing of the $5-\mathrm{HT}_{2 \mathrm{C}}$ receptor.

\section{MATERIALS AND METHODS ANIMALS}

All experiments involving animals were approved by the Institutional Animal Care and Use Committee of Vanderbilt University. Naive adult mice, 3-6 months of age, were used for all experiments. Mice were housed in groups of 2-5 in a temperature controlled, colony room (ambient temperature $22-23^{\circ} \mathrm{C}, 12: 12$ light: dark cycle). Food and water were available ad libitum, and all testing occurred between 1200 and 1700 during the light phase. Unless otherwise indicated, male mice were used.

Mutant mice solely expressing 5- $\mathrm{HT}_{2 \mathrm{C}-\mathrm{VGV}}$ receptors were generated by homologous recombination using a replacement-type targeting vector with the five edited adenosine residues of the $5-\mathrm{HT}_{2 \mathrm{C}}$ receptor gene mutated to guanosine to mimic the base-pairing properties of inosine (Morabito et al., 2007). Mice were maintained on a mixed JAX ${ }^{\circledast}$ 129S1/Taconic 129 S6 background. Four genotypes of mice were used in the experiments examining functional characteristics of the in vivo expressed 5- $\mathrm{HT}_{2 \mathrm{C}-\mathrm{VGV}}$ receptor: wildtype males and females (WT), heterozygous females (VGV/X), and hemizygous (the $5-\mathrm{HT}_{2 \mathrm{C}}$ receptor is X-linked) males (VGV/Y), expressing solely the VGV isoform. The genotypes of mice were determined by PCR analysis of genomic DNA from tail samples using the RED Extract-N-Amp tissue PCR kit (Sigma, St. Louis, MO, USA), with the following primers: 5'GGG CAA ATA TTC TGA AAA GAT GTT 3' (reverse) and 5'AAT ATC AAT AGG TAA TTA TAC C 3' (forward).

To assess the possible contribution of gene dosing, heterozygous mice expressing a mixture of receptor isoforms enriched with the mutant allele were used; these studies were performed in female mice since the $5-\mathrm{HT}_{2 \mathrm{C}}$ receptor is X-linked and it is not possible to generate heterozygote males. Using the method of pyrosequencing (Canal et al., 2009), we verified that heterozygous VGV/X females had VGV as the major isoform, while control mice $(N=4$, average of 60 sequences per mouse) had less than $1 \%$ VGV isoforms. VGV/X females $(N=4$, average of 60 sequences per mouse $)$ had an average of $62 \%$ of RNA isoforms that translate to VGV (Figure 1A); although suggestive of biased $\mathrm{X}$-inactivation, this value was not significantly different from the expected 50\% (one sample $t$-test, $t=3.0949, \mathrm{~d} f=3, p>0.05$ ). The finding that the frequency of VGV isoform in the heterozygous VGV/X mice is about 50\%, combined with subsequent results showing that receptor density in VGV/X mice is about halfway between WT and VGV/Y mice, suggests that there is not significant bias in $\mathrm{X}$-inactivation. We also verified that the increase in the percentage of the VGV isoform in brains of $\mathrm{VGV} / \mathrm{X}$ mice did not alter the remaining distribution of isoforms (Figure 1B).

\section{DRUGS AND RADIOLIGANDS}

MK212 hydrochloride [6-Chloro-2-(1-piperazinyl) pyrazine hydrochloride], purchased from Tocris Bioscience (Ellisville, MO, USA), was dissolved in deionized water, and injected subcutaneously (s.c.) at a volume of $10 \mathrm{ml} / \mathrm{kg}$. $\left[\mathrm{N}^{6}\right.$-methyl- $\left.{ }^{3} \mathrm{H}\right]$-Mesulergine $\left(\left[{ }^{3} \mathrm{H}\right]\right.$-mesulergine) was purchased from GE Healthcare/ Amersham (Buckinghamshire, UK). ( \pm )-1-(2,5,-dimethoxy4-[ $\left.{ }^{125} \mathrm{I}\right]$ iodophenyl)-2-aminopropane ([$\left.{ }^{125} \mathrm{I}\right]$-DOI) was purchased from Perkin Elmer (Boston, MA, USA). Spiperone and methysergide were purchased from Sigma-Aldrich (St. Louis, MO, USA); SB206553 was purchased from Tocris Bioscience.

\section{GTP-SENSITIVE HIGH-AFFINITY AGONIST BINDING IN MEMBRANES}

Agonists, such as DOI, bind preferentially to $5-\mathrm{HT}_{2 \mathrm{C}}$ receptors existing in a high-affinity state, a receptor conformation that is coupled to G-protein. In vitro, $5-\mathrm{HT}_{2 \mathrm{C}-\mathrm{VGV}}$ receptors show no basal coupling to G-proteins (Herrick-Davis et al., 1999; Niswender et al., 1999). We tested whether this recapitulates in brain. Mice were briefly anesthetized using isoflurane and decapitated. Unless otherwise indicated, brains were removed, placed in a slicing mold, and sliced coronally at the level of the optic chiasm. Tissue anterior to the cut, defined here as forebrain, was assayed. Tissue was homogenized in $20 \mathrm{ml}$ of ice cold binding buffer (50 mM Tris, $10 \mathrm{mM} \mathrm{MgCl}_{2}, 0.1 \%$ ascorbic acid, $\mathrm{pH} 7.4)$. Homogenates were centrifuged at 15,000 $\times \mathrm{g}$ for $20 \mathrm{~min}$. at $4^{\circ} \mathrm{C}$. Supernatant was decanted, and the pellet was re-suspended in fresh binding buffer and incubated at $37^{\circ} \mathrm{C}$ for $15 \mathrm{~min}$ to dissociate endogenous ligand from receptors. After a second centrifugation, supernatant was decanted, and the pellet re-suspended in fresh, cold binding buffer. Binding assays were run on the same day as the membrane preparation to avoid a decrease in signal due to freezing.

$\left[{ }^{125} \mathrm{I}\right]$-DOI saturation binding was performed on membranes from VGV/Y and WT mice to test potential differences in the proportion of receptors in the agonist high-affinity conformation. Assays were carried out in triplicate and incubated for $90 \mathrm{~min}$ in a $37^{\circ} \mathrm{C}$ water bath at final volume of $600 \mu \mathrm{l}$, consisting of $500 \mu \mathrm{l}$ of membrane suspension, $1 \mu \mathrm{M}$ spiperone to mask $5-\mathrm{HT}_{2 \mathrm{~A}}$ and $5-\mathrm{HT}_{7}$ binding sites and increasing concentrations of $\left[{ }^{125} \mathrm{I}\right]-\mathrm{DOI}$. Non-specific binding was determined in the presence of $100 \mu \mathrm{M}$ methysergide. Data were analyzed using nonlinear regression (GraphPad Prism 5.02, Graphpad Inc., USA). In a separate experiment, GTP sensitivity was evaluated using a single concentration of $\left[{ }^{125} \mathrm{I}\right]$-DOI $(1 \mathrm{nM})$ in the absence and presence of $200 \mu \mathrm{M}$ guanylyl5 -imidodiphosphate (Gpp(NH)p), a non-hydrolyzable analog of GTP that prevents G-protein coupling. Total density was estimated in each membrane preparation using a single saturating concentration $(30 \mathrm{nM})$ of $\left[{ }^{3} \mathrm{H}\right]$-mesulergine. 


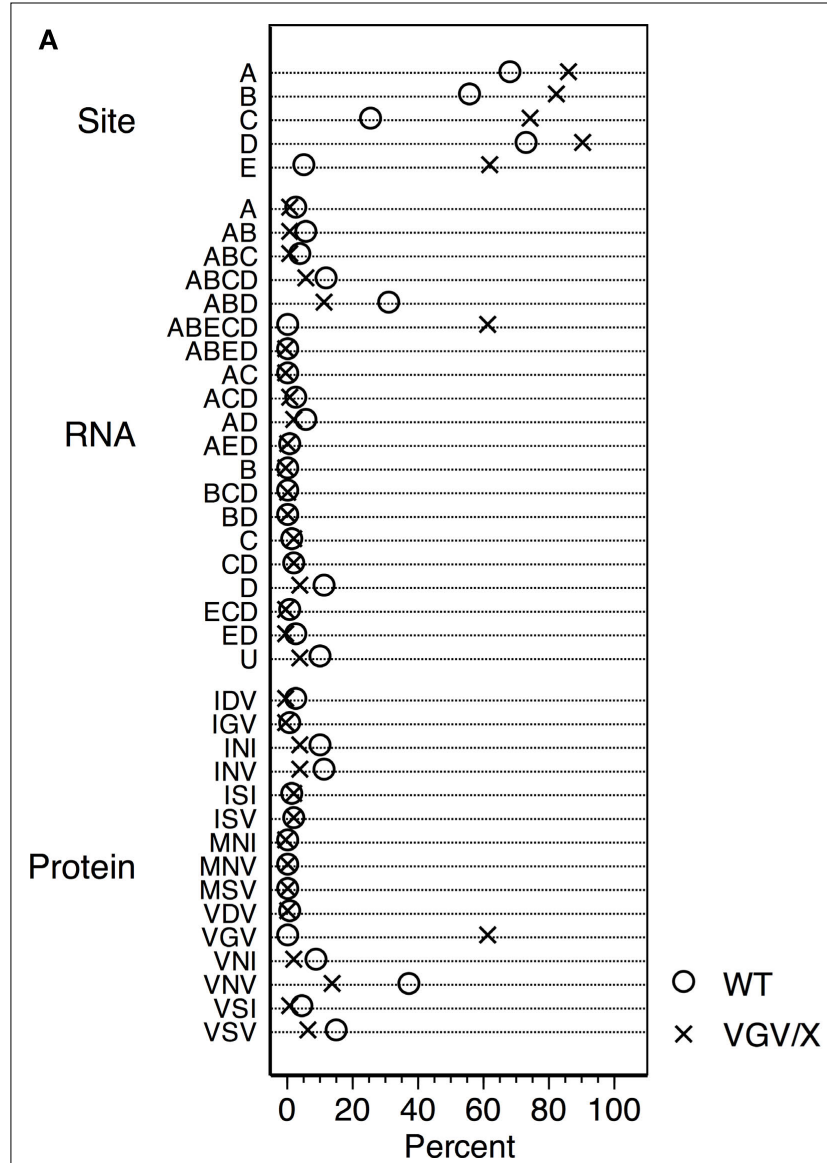

FIGURE 1 | Distribution of $5-\mathrm{HT}_{2 \mathrm{C}}$ RNA isoforms. (A) Percentage distribution of Htr2c RNA editing in cortex of wild type (WT, O) control female mice and heterozygous VGV/X (X) transgenic mice, for editing sites (top), observed RNA sequences (middle), and predicted receptor protein isoforms (bottom). Differences in other proportions (e.g., ABD, VNV) reflect inclusion of VGV in the calculation of the editing measures (\%). Heterozygous VGV/X females expressed the $5-\mathrm{HT}_{2 \mathrm{C}-\mathrm{VGV}}$ isoform at a quantity (mean $=61.9 \%, 95 \%$
B

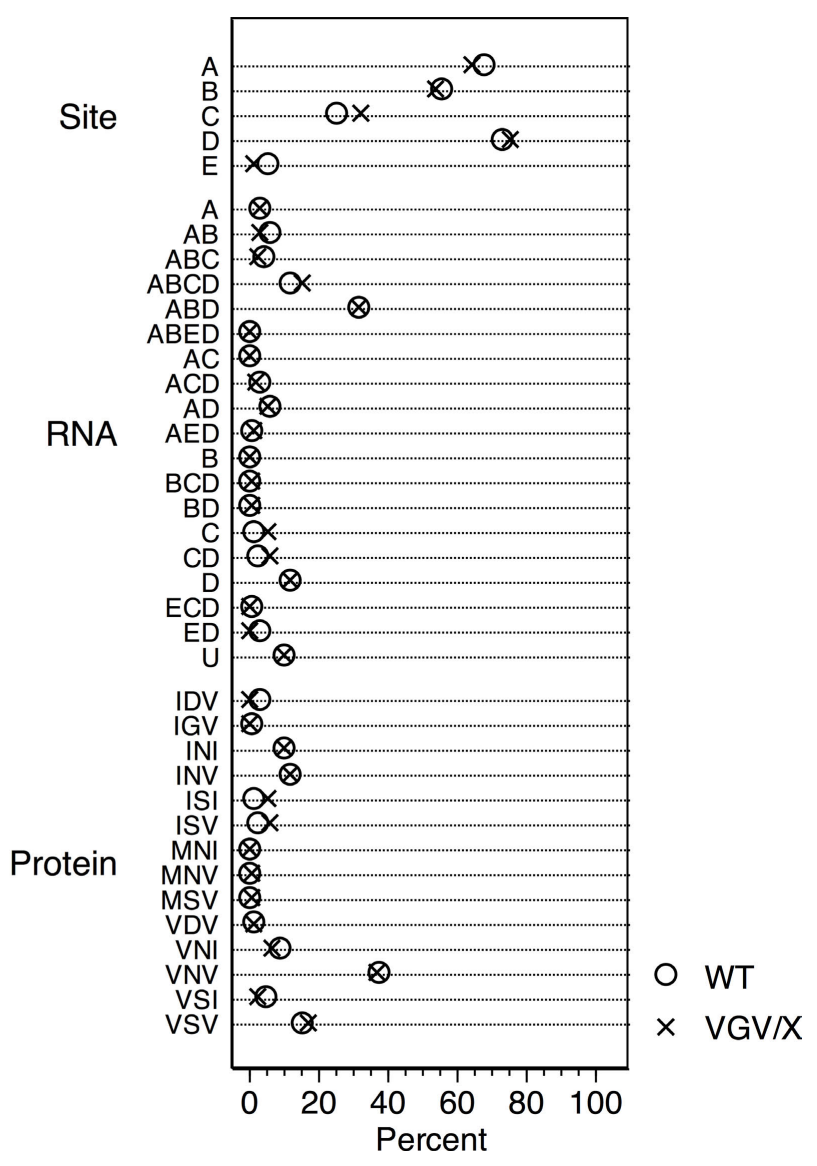

$\mathrm{Cl}$ 49.7-74.1\%) that was significantly higher than the rare expression observed in wild type litter mate females (two sample $t$-test, $t=15.89, \mathrm{~d} f=6, p<0.0001$ ) and significantly lower than the $100 \%$ expression seen in VGV homozygous females and hemizygous VGV/Y males (one sample $t$-test, $t=-9.92, \mathrm{~d} f=3$, $p=0.002$ ). (B) Percentage distribution of Htr2c RNA excluding the fully edited sequences ( $A B E C D$ or VGV) shows that the remaining distribution is unaltered by the presence of a VGV transgenc (Fischer's exact Chi-square test $p=0.37$ ).
Samples were incubated for $90 \mathrm{~min}$ in a $37^{\circ} \mathrm{C}$ water bath, and the reactions were terminated by the addition of ice-cold $50 \mathrm{mM}$ Tris buffer. Membranes were collected by vacuum filtration (Brandel harvester) using Whatman GF/B glass fiber filters presoaked in $0.3 \%$ polyethyleneimine. Filters were rinsed three times with cold Tris buffer, and the bound radioactivity was determined by liquid scintillation spectrometry after soaking filters overnight in scintillation cocktail (Aquasol-2, PerkinElmer, Boston, MA, USA).

\section{[25I]-DOI AND [ $\left.{ }^{3} \mathrm{H}\right]-M E S U L E R G I N E$ AUTORADIOGRAPHY}

Mice were anesthetized with isoflurane inhalation, followed by decapitation. Brains were quickly removed and frozen in 2-methylbutane on dry ice, dried briefly with a Kimwipe (KimberlyClark, Roswell, GA, USA), wrapped in aluminum foil and stored at $-80^{\circ} \mathrm{C}$. Brains were brought to $-20^{\circ} \mathrm{C}$ in a cryostat (Leica, Wetzlar, Germany), sectioned at $20 \mu \mathrm{m}$ and thaw mounted onto Superfrost glass slides (Fisher, USA), then stored at $-80^{\circ} \mathrm{C}$ until the autoradiographic assay.
For $\left[{ }^{125} \mathrm{I}\right]$-DOI autoradiography, slides were thawed at room temperature for $30 \mathrm{~min}$, followed by incubation for $30 \mathrm{~min}$ in assay buffer containing $50 \mathrm{mM}$ Tris, $5 \mathrm{mM} \mathrm{MgSO}_{4}, 4 \mathrm{mM} \mathrm{CaCl}_{2}$ and $0.5 \mathrm{mM}$ EDTA. Slides were then transferred to assay buffer that contained one of four drug treatments: (1) $0.14 \mathrm{nM}\left[{ }^{125} \mathrm{I}\right]-\mathrm{DOI}$ to

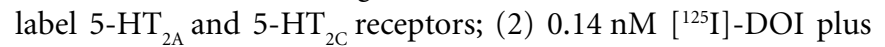
$100 \mathrm{nM}$ spiperone to identify the $5-\mathrm{HT}_{2 \mathrm{C}}$ receptor; (3) $0.14 \mathrm{nM}$ [ $\left.{ }^{125} \mathrm{I}\right]$-DOI plus $100 \mu \mathrm{M}$ GTP $\gamma \mathrm{S}$ to identify GTP-sensitive high affinity $\left[{ }^{125} \mathrm{I}\right]$-DOI binding (Appel et al., 1990); (4) $0.14 \mathrm{nM}\left[{ }^{125} \mathrm{I}\right]-\mathrm{DOI}$ plus $30 \mu \mathrm{M}$ methysergide to define non-specific binding. Slides were incubated with radioligand at room temperature for $60 \mathrm{~min}$, then washed $4 \times 10 \mathrm{~min}$ in ice-cold $50 \mathrm{mM}$ Tris buffer, $\mathrm{pH} 7.4$ and dried with a steady stream of dehumidified air.

$\left[{ }^{3} \mathrm{H}\right]$-mesulergine autoradiography procedures were identical to $\left[{ }^{125} \mathrm{I}\right]$-DOI autoradiography with the following exceptions. The assay buffer for $\left[{ }^{3} \mathrm{H}\right]$-mesulergine was $50 \mathrm{mM}$ Tris, $10 \mathrm{mM} \mathrm{MgCl}$, and $0.1 \mathrm{mM}$ EDTA. The binding conditions were: (1) $3 \mathrm{nM}\left[{ }^{3} \mathrm{H}\right]-$ mesulergine; (2) $3 \mathrm{nM}\left[{ }^{3} \mathrm{H}\right]$-mesulergine plus $100 \mathrm{nM}$ spiperone; (3) $3 \mathrm{nM}\left[{ }^{3} \mathrm{H}\right]$-mesulergine plus $30 \mu \mathrm{M}$ methysergide to define 
non-specific binding. The addition of $300 \mathrm{nM} \mathrm{SB} 204741$, a 5- $\mathrm{HT}_{2 \mathrm{~B}}$ antagonist, did not alter $\left[{ }^{3} \mathrm{H}\right]$-mesulergine binding in $\mathrm{WT}$ or VGV/Y brain slices.

Slides were incubated for $120 \mathrm{~min}$ at room temperature, then washed $4 \times 10 \mathrm{~min}$ in ice-cold $50 \mathrm{mM}$ Tris buffer, $\mathrm{pH} 7.4$ and dried with a steady stream of dehumidified air.

After air drying for an additional $90 \mathrm{~min}$, slides were placed in autoradiography cassettes and exposed to Kodak Biomax MR film (Carestream Health, Inc., USA) for $24-48 \mathrm{~h}$ for $\left[{ }^{125} \mathrm{I}\right]-\mathrm{DOI}$ or 6-8 weeks for ${ }^{3} \mathrm{H}$-mesulergine prior to developing (shorter exposures were required for brain sections from VGV/Y mice to accommodate an increased density of 5- $\mathrm{HT}_{2 \mathrm{C}}$ receptors). Film was scanned (CanoScan 4400F, Canon, USA) onto a PC, and images were analyzed with Image J software (Abramoff et al., 2004). The average of the minimum gray value (darkest area) from three brain slices containing brain area of interest was converted to $\mu \mathrm{Ci} / g$ protein using ${ }^{14} \mathrm{C}$ standards (ARC, Inc., St. Louis, MO) for statistical comparisons of specific $\left[{ }^{125} \mathrm{I}\right]-\mathrm{DOI}$ binding, and ${ }^{3} \mathrm{H}$ standards for statistical comparisons of specific $\left[{ }^{3} \mathrm{H}\right]$-mesulergine. Data were compared using 2-tailed unpaired $t$-tests.

\section{5-HT ${ }_{2 C}$ RECEPTOR AGONIST IMPACT ON LOCOMOTOR ACTIVITY IN VGV/Y AND VGV/X}

Dose-response studies were conducted to assess the locomotor effects of $\mathrm{MK} 212$, a preferential $5-\mathrm{HT}_{2 \mathrm{C}}$ receptor agonist (Fone et al., 1998; Gleason et al., 2001; Stiedl et al., 2007; Fletcher et al., 2009) in WT, hemizygous VGV/Y and heterozygous VGV/X mice. Locomotor activity was measured in Plexiglas activity chambers $(11 \times 11 \times 11$ in; LxWxH; Med Associates St. Albans, Vermont $)$, equipped with 16 infrared beams to monitor and record beam breaks in the $x-y-z$ coordinates. VGV/Y and VGV/X mice were tested with saline and MK212 at doses of 0.01, 0.03, 0.1, 0.3 and $1.0 \mathrm{mg} / \mathrm{kg}$. Twenty minutes after s.c. injection, individual mice were placed inside the activity chamber and distance traveled was recorded for $10 \mathrm{~min}$ using Activity Monitor software version 5 (Med Associates, St. Albans, Vermont, USA). Dose-response data were analyzed by two-way ANOVA for independent groups.

\section{BIOGENIC AMINE TURNOVER IN VGV/Y MICE}

Dopamine (DA), serotonin (5-HT) and metabolites were quantified by high-performance liquid chromatography (HPLC) electrochemical detection methods (Vanderbilt Neurochemistry Core). Animals were anesthetized with isoflurane and rapidly decapitated after cervical dislocation. Brains were removed and placed in a chilled stainless steel mold for dissection - the tissue slice 1.7-3.6 relative to bregma is referred to as frontal cortex; striatum represents slice 1.70 to -0.82 relative to bregma with the cortex removed by freehand dissection. Tissue was frozen rapidly on dry ice and stored at $-80^{\circ} \mathrm{C}$ until assay. Thawed samples were homogenized in $250 \mu \mathrm{l}$ acetonitrile and centrifuged at $13,000 \times \mathrm{g}$ for $30 \mathrm{~min}$. The acetonitrile fraction was transferred to a clean tube, washed twice with $125 \mu \mathrm{l}$ heptane and then evaporated using a stream of nitrogen. The sample was suspended in $75 \mu$ of the HPLC mobile phase ( $37.5 \mathrm{mmol} \mathrm{H}_{3} \mathrm{PO}_{4}, \mathrm{pH} 8.5$ ) and $50 \mu \mathrm{l}$ was injected into the equilibrated HPLC. DA turnover was measured by the ratio DOPAC/DA and HVA/DA; 5-HT turnover was measured by the ratio 5-HIAA/ 5 -HT. Each measure was predicted by a mixed ANOVA model that incorporated between-subject fixed effects for genotype (VGV/Y or WT) and drug (saline or SB206553), a within-subject fixed effect for brain area (frontal cortex or striatum), and a random effect to account for repeated measures in each mouse.

\section{[ $\left.{ }^{3} \mathrm{H}\right]-M E S U L E R G I N E$ SATURATION BINDING IN MEMBRANES}

The procedures for $\left[{ }^{3} \mathrm{H}\right]$-mesulergine saturation binding were essentially identical to [ $\left.{ }^{125} \mathrm{I}\right]$-DOI binding in membranes. Membrane homogenates, binding buffer, spiperone at a final concentration of $1 \mu \mathrm{M}$, and increasing concentrations of $\left[{ }^{3} \mathrm{H}\right]$-mesulergine up to $36 \mathrm{nM}$ were added. Non-specific binding was determined in the presence of $100 \mu \mathrm{M}$ methysergide.

\section{RESULTS}

\section{5-HT ${ }_{2 C-v G V}$ RECEPTORS IN BRAIN EXHIBIT REDUCED HIGH-AFFINITY AGONIST BINDING: MEMBRANE BINDING}

In saturation binding assays of membranes from WT littermates, the binding of the radiolabeled agonist $\left[{ }^{125} \mathrm{I}\right]$-DOI was best fit by a two-site equation, as illustrated in the Scatchard plot (Figure 2A). Approximately $10 \%$ of the binding sites were in a high affinity state $\left(K_{\mathrm{d}}=0.51 \mathrm{nM}\right)$.The low-affinity site had a $K_{\mathrm{d}}(20 \mathrm{nM})$ and density of $137 \mathrm{fmol} / \mathrm{mg}$ protein. In contrast, $\left[{ }^{125} \mathrm{I}\right]$-DOI binding in membranes from VGV/Y mice was best fit by a one-site equation, as illustrated in the Scatchard plot (Figure 2B) with a $K_{d}(29 \mathrm{nM})$ that was consistent with the $K_{\mathrm{d}}$ of the low affinity site in WT mice. The extremely high density of binding sites in VGV/Y mice was confirmed in $\left[{ }^{3} \mathrm{H}\right]$-mesulergine binding experiments (see below).

To corroborate the finding of decreased high-affinity binding sites in brains of $\mathrm{VGV} / \mathrm{Y}$ mice and to estimate the percentage of G-protein coupled receptors, the binding of a single concentration of $\left[{ }^{125} \mathrm{I}\right]$-DOI was determined in the absence and presence of $\mathrm{Gpp}(\mathrm{NH}) \mathrm{p}$ to uncouple the receptor:G-protein complex (Figure 3). Fifty-seven percent of the $\left[{ }^{125} \mathrm{I}\right]$-DOI binding in membranes from WT mice was eliminated by addition of $\mathrm{Gpp}(\mathrm{NH}) \mathrm{p}$; in contrast $\left[{ }^{125} \mathrm{I}\right]$-DOI binding in membranes from VGV/Y mice was $\mathrm{Gpp}(\mathrm{NH}) \mathrm{p}$-insensitive (Figure 3).

\section{5-HT ${ }_{2 \mathrm{C}-\mathrm{GG}}$ RECEPTORS IN VIVO EXHIBIT REDUCED GTP-SENSITIVE HIGH AFFINITY AGONIST BINDING: [25I]-DOI AUTORADIOGRAPHY}

$\left[{ }^{125} \mathrm{I}\right]$-DOI binding to $5-\mathrm{HT}_{2 \mathrm{C}}$ receptors was clearly visible in the choroid plexus in brain slices from WT and VGV/Y mice; thus the choroid plexus was used for analysis of GTP sensitivity of 5$\mathrm{HT}_{2 \mathrm{C}}$ receptor binding. As illustrated in Figure 4, the addition of GTP $\gamma S$ to WT sections incubated with $\left[{ }^{125} \mathrm{I}\right]$-DOI decreased specific binding in choroid plexus $(45.7 \pm 6.52 \%$ decrease; $N=5 ; p<0.05)$. However, GTP $\gamma S$ did not significantly alter $\left[{ }^{125} \mathrm{I}\right]$-DOI binding in choroid plexus of $\mathrm{VGV} / \mathrm{Y}$ sections $(5.5 \pm 3.9 \%$ decrease; $N=6$; $p=0.15)$, confirming greatly reduced high-affinity, GTP-sensitive, agonist binding at $5-\mathrm{HT}_{2 \mathrm{C}-\mathrm{VGV}}$ receptors.

\section{VGV/Y MICE HAVE INCREASED SENSITIVITY TO 5-HT ${ }_{2 \mathrm{C}}$ RECEPTOR AGONIST: LOCOMOTOR ACTIVITY}

Injection of the 5- $\mathrm{HT}_{2 \mathrm{C}}$ agonist, MK212, dose-dependently decreased total distance traveled in all genotypes, yet the potency of MK212 was greater in mutant mice relative to their respective WT littermates. For WT, female VGV/X and VGV/Y mice (Figure 5), a 2-way ANOVA revealed main effects of dose $\left(F_{5,135}=31.77\right.$, 

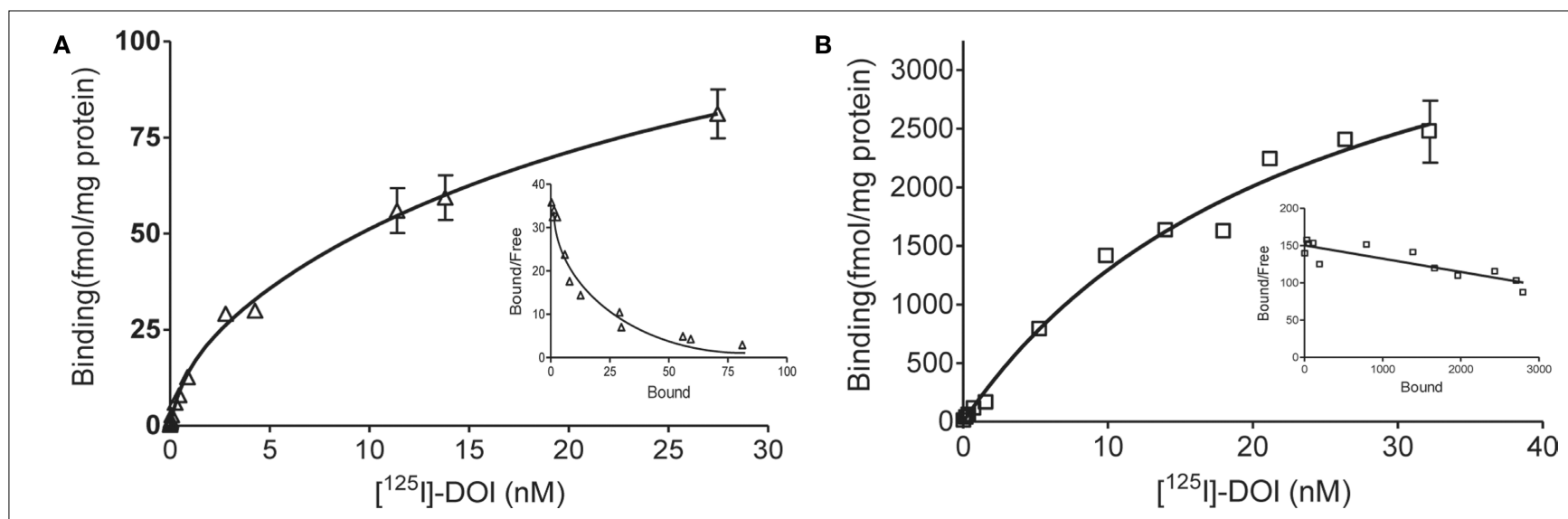

FIGURE 2 |Agonist high affinity binding: Membranes from WT and VGV/Y mice. Representative saturation plots of specific [ $\left.{ }^{125} \mathrm{l}\right]$-DOI binding are shown for membranes from WT (A), and VGV/Y mice (B). Increasing concentrations of $\left[{ }^{125} \mathrm{I}\right]$-DOI are plotted on the $x$-axis and density (fmol/mg protein) is plotted on the

$y$-axis. Data were tested for best fit to one- or two-site models (GraphPad Prism 5.02). Insets show Scatchard transformation of the saturation binding data, bound/free ( $y$-axis) versus bound ( $x$-axis). Scatchard plots illustrate the absence of high-affinity agonist binding sites in VGV/Y mice.

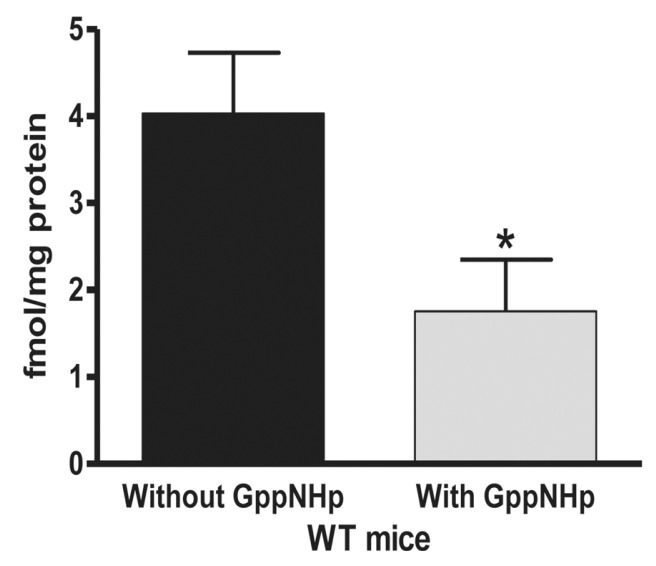

FIGURE 3 | GTP sensitive agonist binding: Membranes from WT and VGV/Y. Gpp(NH)p (200 $\mu \mathrm{M})$ was added to assay buffer containing $1 \mathrm{nM}$ $\left[{ }^{125}\right]$-DOI to eliminate high affinity binding; the [ $\left.{ }^{125} \mid\right]-D O I$ binding in the absence

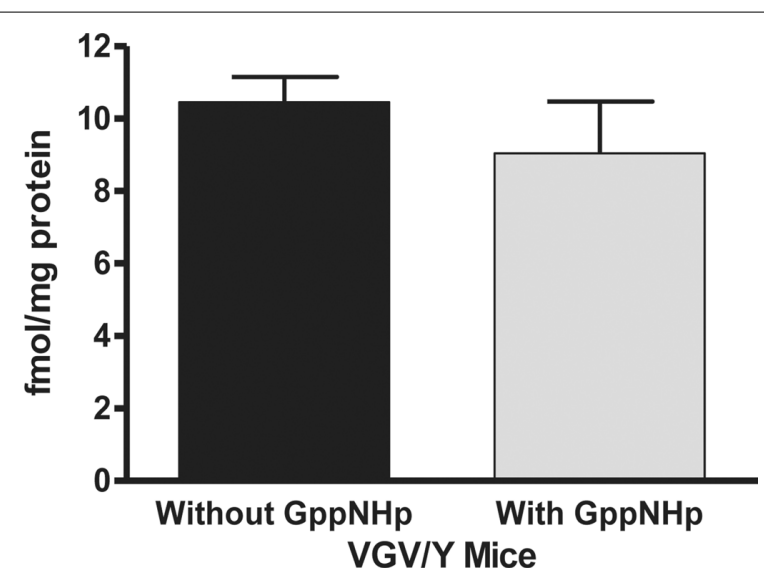

and presence of Gpp(NH)p is plotted. Membranes from VGV/Y show no detectable GTP-sensitive $\left[{ }^{125} \mathrm{I}\right]$-DOI binding to $5-\mathrm{HT}_{2 \mathrm{C}}$ receptors. A significant effect of genotype was observed $\left(F_{1,43}=54.66, p<0.0001\right)$.

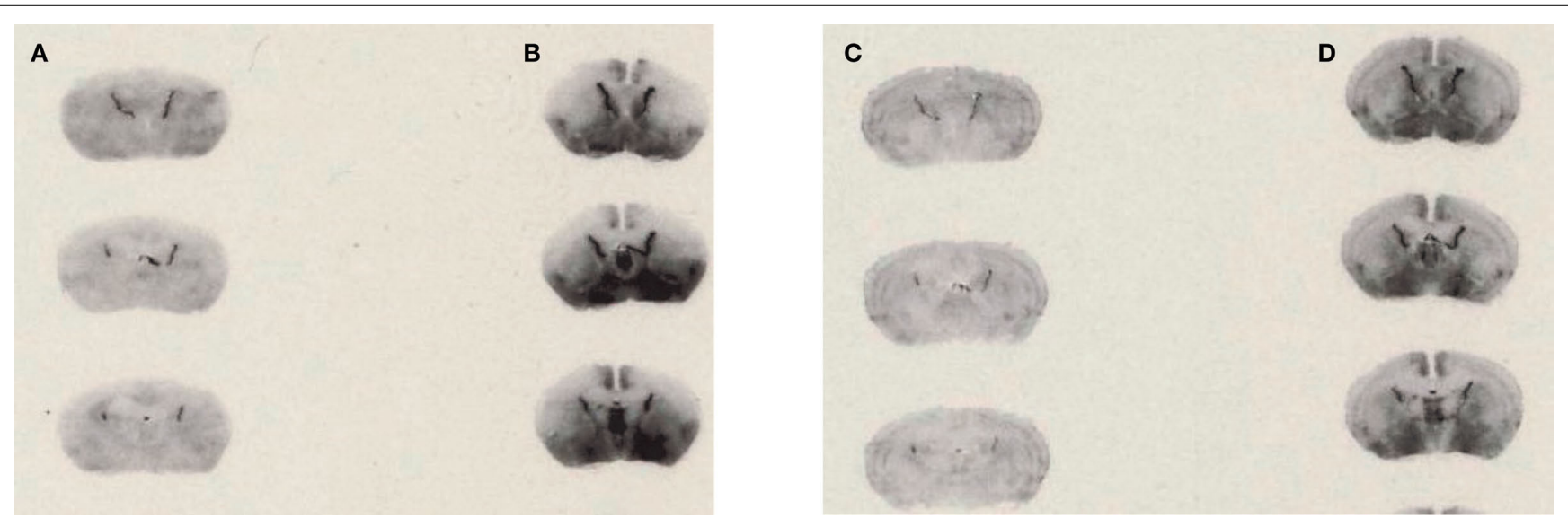

FIGURE 4 | Agonist high affinity binding: autoradiography of brain slices from WT and VGV/Y mice. Representative [125]]-DOI autoradiography. (A) WT sections incubated in $0.14 \mathrm{nM}\left[{ }^{125}\right]$-DOI plus $1 \mu \mathrm{M}$ spiperone. (B) VGV/ sections incubated in $0.14 \mathrm{nM}\left[{ }^{125}\right]$ ]-DOI plus $1 \mu M$ spiperone. (C)WT sections incubated in $0.14 \mathrm{nM}$

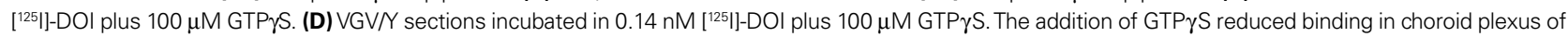
sections from WT, but not VGV $Y$ mice. 
$p<0.0001)$ and genotype $\left(F_{2,135}=42.46, p<0.0001\right)$. The potency of MK212 was 10-fold higher in VGV/Y and VGV/X mice relative to WT's (Figure 5; $N=10$ ). For example, $0.1 \mathrm{mg} / \mathrm{kg} \mathrm{MK} 212$ essentially eliminated locomotor activity in VGV/Y mice (post-hoc Fisher least significant difference (LSD) test, saline vs. $0.1 \mathrm{mg} / \mathrm{kg}$, $p<0.001)$, whereas this dose did not reduce locomotor activity in WT mice (post-hoc Fisher LSD test, saline vs. $0.1 \mathrm{mg} / \mathrm{kg}, p=0.58$ ). There were no gender differences in the motor effects of MK212 in WT mice (data not shown).

\section{VGV/Y MICE HAVE INCREASED SENSITIVITY TO 5-HT ${ }_{2 \mathrm{C}}$ RECEPTOR INVERSE AGONIST: DA TURNOVER}

Given that the $5-\mathrm{HT}_{2 \mathrm{C}}$ receptor has been reported to exert an inhibitory influence on DA release, we asked if the DA turnover is decreased in VGV/Y mice and further if SB206553 differentially altered DA turnover. Twenty minutes after treatment with saline or $3 \mathrm{mg} / \mathrm{kg}$ of the inverse agonist SB206553, biogenic amine levels were determined in striatum and cortex of $\mathrm{VGV} / \mathrm{Y}$ and WT male mice (Table 1). DA turnover was measured by the ratio DOPAC/DA and the ratio HVA/DA, and 5-HT turnover was measured by the ratio 5-HIAA/5-HT. Each measure was predicted by a mixed ANOVA model that incorporated between-subject fixed effects for genotype

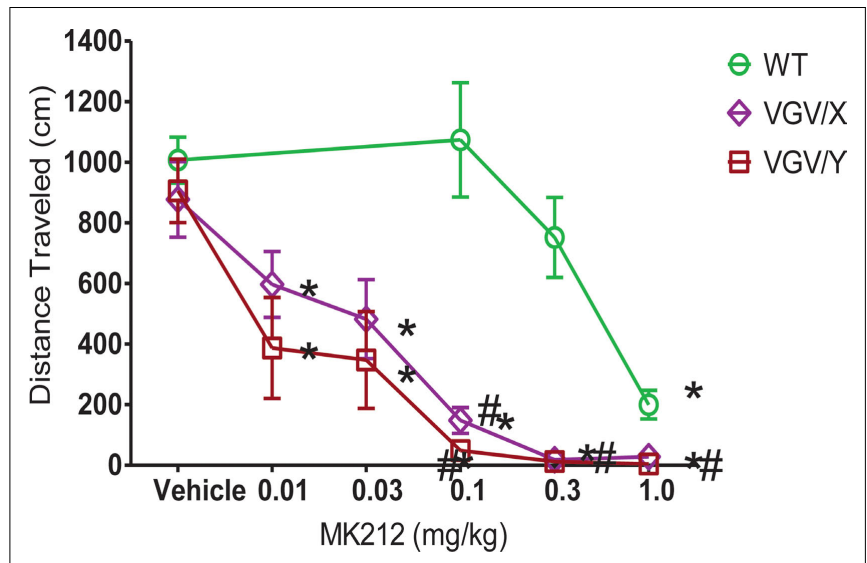

FIGURE 5 | MK212 dose-dependent induction of hypolocomotion. Locomotor activity of WT, VGV/X, and VGV/Y mice after single subcutaneous injection of saline or MK2I2 $(0.01,0.03,0.1,0.3$ or $1.0 \mathrm{mg} / \mathrm{kg})$. *Denotes significantly different from saline within group. "Denotes significantly different from WT.
(VGV/Y or WT) and drug (saline or SB206553), a within-subject fixed effect for brain area (cortex or striatum), and a random effect to account for repeated measures in each mouse.

Although basal DA turnover (saline treated) was reduced in cortex of VGV/Y mice ( $p=0.039$ for DOPAC/DA, $p=0.063$ for HVA/DA, least-squared difference post-hoc tests, Figures 6A,B), this effect was small and not reproduced in the striatum. A more striking dopamine phenotype occurred in both cortex and striatum following SB206553 challenge. Significant genotype by drug interactions were observed for the ratios DOPAC/DA (Figure 6A), HVA/DA (Figure 6B), and for 5-HIAA/5-HT (Figure 6C). Similar interaction profiles of the marginal means were observed for each turnover measure (Figure 6), where VGV/Y mice showed significantly increased turnover after SB206553 challenge compared to saline, but WT mice revealed a relatively flatter profile across saline and SB206553 conditions.

\section{VGV/Y MICE SHOW LARGE INCREASES IN 5-HT ${ }_{2 C}$ RECEPTOR DENSITY: [ $\left.{ }^{3} \mathrm{H}\right]-M E S U L E R G I N E$ SATURATION BINDING}

$\left[{ }^{3} \mathrm{H}\right]$-Mesulergine saturation binding was performed to determine the maximum density of $5-\mathrm{HT}_{2 \mathrm{C}}$ receptor binding sites in brains of WT, VGV/Y and VGV/X mice (Figure 7). All plots were best fit by a single site equation. The density of $5-\mathrm{HT}_{2 \mathrm{C}}$ receptors in the forebrain was increased by 25 -fold in VGV/Y mice relative to WT mice $\left(B_{\max }=163.3 \pm 5.9 \mathrm{fmol} / \mathrm{mg}\right.$ protein in WT vs. $4266 \pm 260 \mathrm{in}$ $\mathrm{VGV} / \mathrm{Y} ; N=4)$. Heterozygous VGV/X mice displayed an approximately 10 -fold increase in the density of $\left[{ }^{3} \mathrm{H}\right]$-mesulergine binding sites $\left(B_{\max }=1754 \pm 149 \mathrm{fmol} / \mathrm{mg}\right.$ protein; $\left.N=8\right)$, which was intermediate to that observed for WT and VGV/Y mice. The $K_{d}$ values for $\left[{ }^{3} \mathrm{H}\right]$-mesulergine were identical in all three genotypes. Furthermore, in competition binding experiments, the Ki values for MK212, SB206553 and spiperone were not altered in membranes from VGV/Y vs WT mice (data not shown).

\section{VGV/Y MICE SHOW LARGE INCREASES IN 5-HT ${ }_{2 \mathrm{C}}$ RECEPTOR DENSITY: [ $\left.{ }^{3} \mathrm{H}\right]-M E S U L E R G I N E$ AUTORADIOGRAPHY}

Similar to results of saturation binding experiments, $\left[{ }^{3} \mathrm{H}\right]-$ mesulergine autoradiograms showed tremendous increases in $5-\mathrm{HT}_{2 \mathrm{C}}$ receptor density in $\mathrm{VGV} / \mathrm{Y}$ mice (Figure 8). WT specific binding versus $\mathrm{VGV} / \mathrm{Y}$ specific binding was significantly increased $(p<0.05)$ in all regions examined [e.g., $89 \%$ increase in nucleus accumbens of VGV/Y mice $(N=6)$ relative to $\mathrm{WT}(N=5)]$. The

Table 1 | Biogenic amines.

\begin{tabular}{|c|c|c|c|c|c|c|c|c|c|c|}
\hline \multirow{2}{*}{$\begin{array}{l}\text { Amine/metabolite } \\
\text { Genotype }\end{array}$} & \multicolumn{2}{|c|}{ DOPAC } & \multicolumn{2}{|c|}{ Dopamine } & \multicolumn{2}{|c|}{ 5-HIAA } & \multicolumn{2}{|c|}{ 5-HT } & \multicolumn{2}{|c|}{ HVA } \\
\hline & WT & VGV & WT & VGV & WT & VGV & WT & VGV & WT & VGV \\
\hline Saline & $7.1 \pm 1.8$ & $10.2 \pm 1.8$ & $31.5 \pm 10.4$ & $68.2 \pm 11.4^{*}$ & $10.4 \pm 0.88$ & $13.6 \pm 1.7$ & $25.9 \pm 1.2$ & $30.8 \pm 2.2$ & $6.7 \pm 1.6$ & $11.2 \pm 1.8$ \\
\hline SB206553 & $6.6 \pm 0.8$ & $15.6 \pm 1.7$ & $28.9 \pm 6.7$ & $34.2 \pm 6.3$ & $9.1 \pm 0.7$ & $16.0 \pm 0.8$ & $24.5 \pm 2.4$ & $20.0 \pm 0.9$ & $6.0 \pm 0.7$ & $13.9 \pm 1.3$ \\
\hline SB206553 & $14.39 \pm 1.4$ & $24.1 \pm 1.0$ & $110.8 \pm 10.7$ & $95.0 \pm 15.1$ & $18.9 \pm 0.7$ & $26.2 \pm 1.1$ & $25.9 \pm 1.8$ & $25.4 \pm 0.6$ & $16.2 \pm 1.3$ & $16.1 \pm 1.1$ \\
\hline
\end{tabular}

The results are presented as means \pm SEM $(n=5)$. * Significantly different from WT, $p<0.01$. Data were analyzed with ANOVAs. 


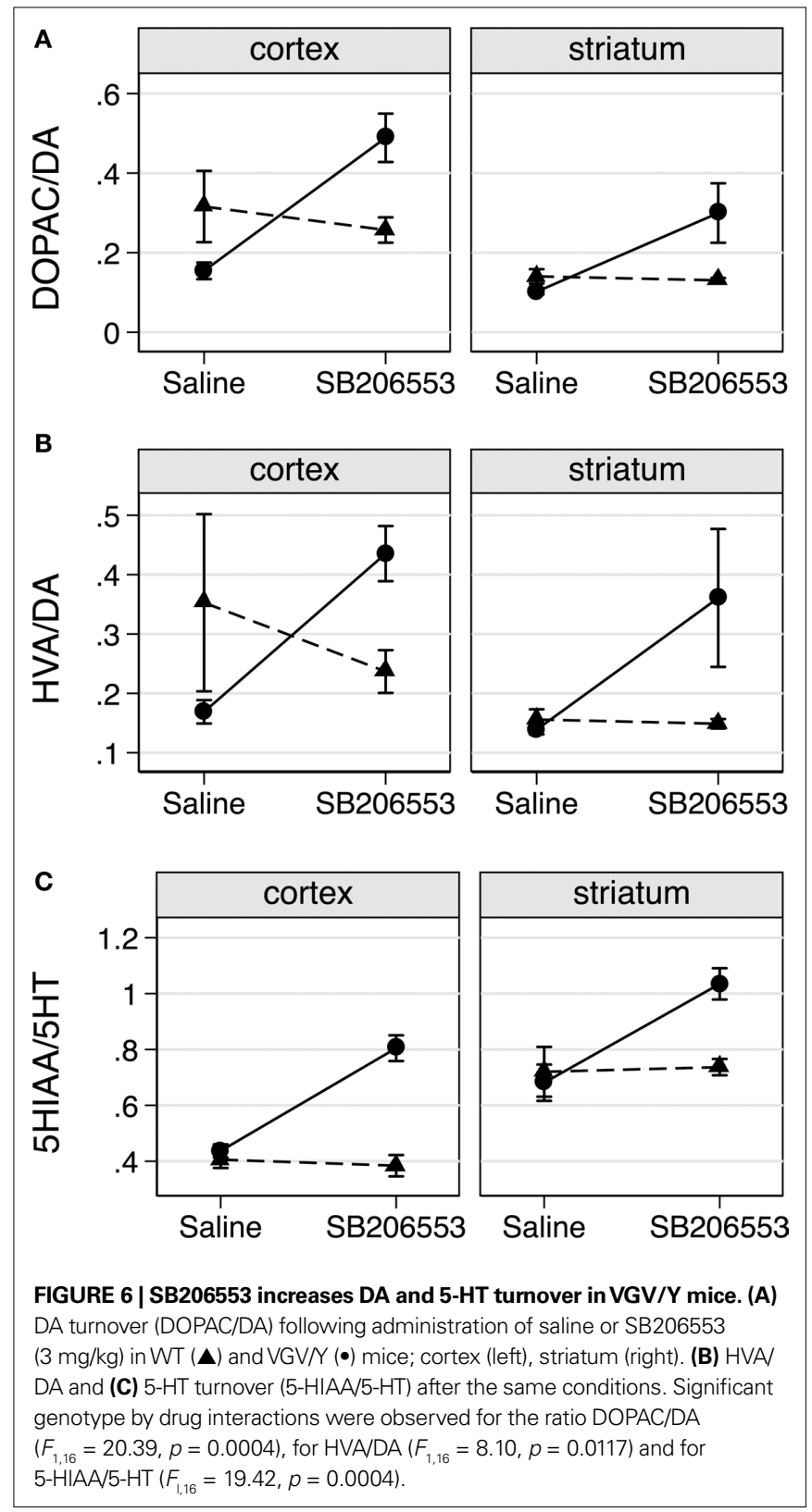

widespread increase in $5-\mathrm{HT}_{2 \mathrm{C}}$ receptor binding in thalamus, amygdala, posterior cingulate cortex, piriform cortex (Figure 8) appears to reproduce the distribution in WT mice, suggesting that overexpression in the mutant mice does not reflect an aberrant distribution of the $5-\mathrm{HT}_{2 \mathrm{C}}$ receptor.

\section{DISCUSSION}

5- $\mathrm{HT}_{2 \mathrm{C}}$ receptor RNA transcripts undergo five adenosine to inosine RNA editing events, resulting in the generation of distinct amino acids in the second intracellular loop of the protein, a region critical for G-protein coupling (Moro et al., 1993; Ballesteros et al., 1998; Gaborik et al., 2003). Combinations of the five edited nucleotides predict 24 different protein isoforms (Burns et al., 1997); many isoforms display altered signaling properties in transfection experiments in cell lines. The fully-edited VGV isoform, where all

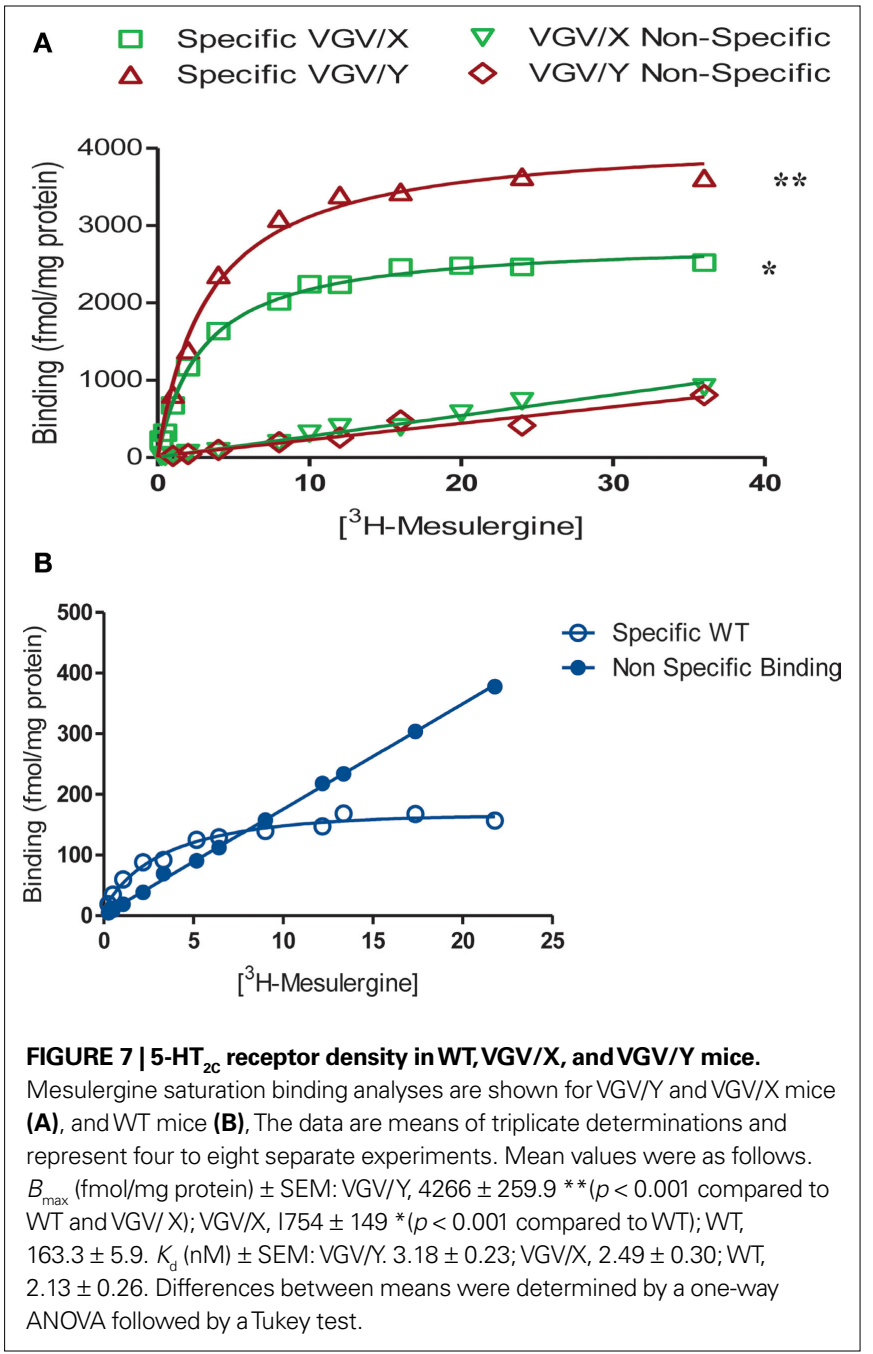

five sites are edited, shows the most dramatic decrease in agonist potency, as well as silencing of receptor constitutive activity and elimination of high-affinity, $\mathrm{Gpp}(\mathrm{NH}) \mathrm{p}$ sensitive agonist binding (Niswender et al., 1999). The current set of experiments takes advantage of genetically modified mice solely expressing the VGV isoform to show, for the first time in brain, that RNA editing of the $5-\mathrm{HT}_{2 \mathrm{C}}$ receptor alters the proximal event in cell signaling, receptor: G-protein coupling.

Several techniques were used to highlight the in vivo properties of the $5-\mathrm{HT}_{2 \mathrm{C}-\mathrm{VGV}}$ receptor including $\left[{ }^{3} \mathrm{H}\right]$-mesulergine saturation binding, $\left[{ }^{3} \mathrm{H}\right]$-mesulergine autoradiography, $\left[{ }^{125} \mathrm{I}\right]$-DOI saturation binding, and $\left[{ }^{125} \mathrm{I}\right]$-DOI GTP-sensitive high affinity binding in membranes and in autoradiography. Nonlinear regression analysis of $\left[{ }^{125} \mathrm{I}\right]$-DOI saturation binding revealed two saturable binding sites in membranes from brains of WT mice, with the high affinity site representing nearly $10 \%$ of the total binding. In contrast, nonlinear regression analysis of $\left[{ }^{125} \mathrm{I}\right]$-DOI saturation binding to membranes from mice expressing the VGV isoform reveals only a single, low-affinity site, even though receptor density is increased dramatically. Based on the extended ternary complex model of receptor:G-protein coupling (Samama et al., 1993), it is likely that the loss of high affinity binding reflects reduced G-protein coupling. 


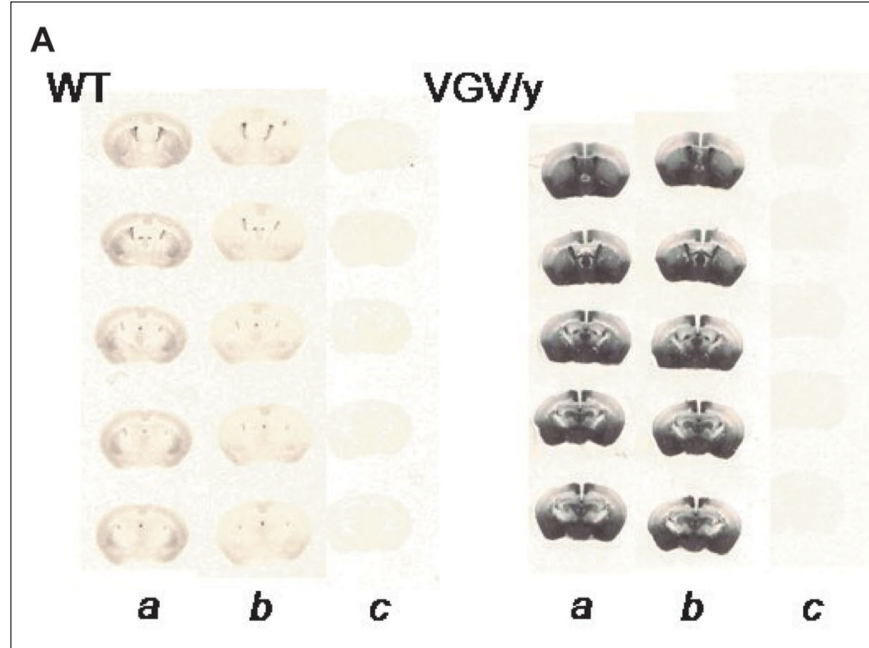

FIGURE 8 | 5- $\mathrm{HT}_{2 \mathrm{C}}$ receptor density and distribution: [ $\left.{ }^{3} \mathrm{H}\right]-$-mesulergine autoradiography in brain slices. (A) Representative $\left[{ }^{3} \mathrm{H}\right]$-mesulergine autoradiography of brain sections from WT and VGV/Y mice. (a) Sections incubated in $3 \mathrm{nM}\left[{ }^{3} \mathrm{H}\right]-$-mesulergine: (b) plus $1 \mu \mathrm{M}$ spiperone: (c) plus $30 \mu \mathrm{M}$ methysergide. (B) Representative $\left.{ }^{3} \mathrm{H}\right]$-mesulergine autoradiographs of brain
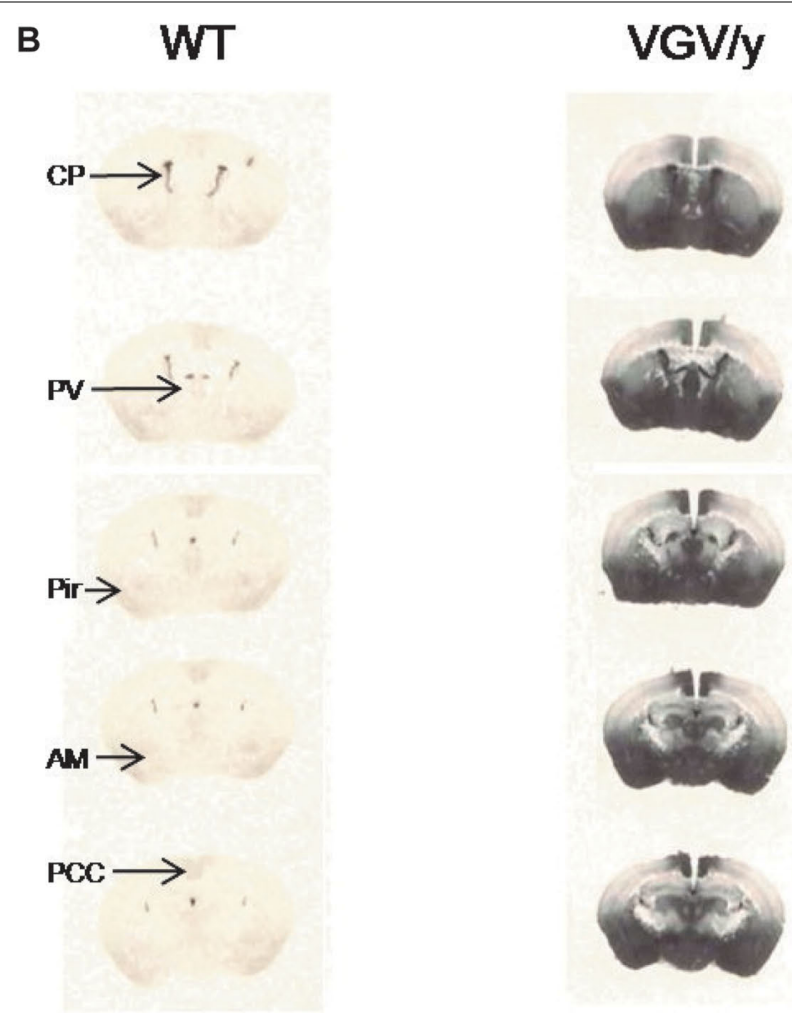

sections displaying $5-\mathrm{H}_{2 C}$ receptors in $\mathrm{WT}$, and VGV/Y mice. Increases in $5-\mathrm{HT}_{2 \mathrm{C}}$-receptor expression in VGV/Y mice are observed in several brain structures. Abbreviations; $\mathrm{CP}$, choroid plexus; $\mathrm{PV}$, paraventricular thalamic nucleus; Pir, piriform cortex; Am, amygdala; PCC, posterior cingulate cortex.
To test this further, $\left[{ }^{125} \mathrm{I}\right]$-DOI binding was carried out in the presence and absence of a GTP analog. The addition of Gpp $(\mathrm{NH}) \mathrm{p}$ reduces the binding of $\left[{ }^{125} \mathrm{I}\right]-\mathrm{DOI}$ in brain membranes from WT mice, but has essentially no effect on $\left[{ }^{125} \mathrm{I}\right]$-DOI binding in membranes from VGV/Y mice, suggesting that the G-protein coupling capacity is compromised in brains of mice solely expressing the 5$\mathrm{HT}_{2 \mathrm{C}-\mathrm{VGV}}$ receptors. An unexpected finding was the marked increase in total $\left[{ }^{125} \mathrm{I}\right]$-DOI binding in brains of VGV/Y mice relative to WT, with a binding site density comparable to that found in the choroid plexus (Conn and Sanders-Bush, 1986). We considered the possibility that $\mathrm{Gq} / 11$ protein may become rate-limiting in the case of the large increase in receptor density in brains of VGV/Y mice. However, quantitative studies of Milligan (1993) show that the level of Gq protein in rat frontal cortex is $17 \mathrm{pmol} / \mathrm{mg}$ protein and combined Gq/G11, $25 \mathrm{pmol} / \mathrm{mg}$ protein, which is five-fold higher than receptor density in VGV/Y mice. Furthermore, we have previously shown that the levels of Gq and G11 protein are not altered in VGV/Y mice (Canal et al., 2009). These findings suggest that $\mathrm{Gq} / 11$ protein is not rate limiting in the brains of VGV/Y and that the reduction in GTP-sensitivity reflects reduced coupling capacity of the VGV isoform.

Consistent with a reduction in G-protein coupling capacity found in membranes prepared from brains of VGV/Y mice, receptor autoradiography in intact brain slices reveals that, although total ${ }^{3} \mathrm{H}$-mesulergine binding is increased, the proportion of GTP-sensitive high affinity $\left[{ }^{125} \mathrm{I}\right]$-DOI binding is reduced nearly eight-fold in choroid plexus of VGV/Y mice. These experiments confirm that the blunted G-protein coupling of the VGV isoform described in cell lines is reproduced in a native setting. We conclude therefore that it is valid to interpret in vivo increases in the degree of RNA editing of the $5-\mathrm{HT}_{2 \mathrm{C}}$ receptor as a loss of function at the cellular level. An attempt to evaluate the classical effector pathway, Gq mediated-PLC activation, was unsuccessful; 5-HT failed to elicit a PLC signal in cortical tissue from wild-type or VGV/Y mice. Previous studies of 5- $\mathrm{HT}_{2 \mathrm{C}}$ receptor-mediated PLC activation in rat brain were performed in choroid plexus (Conn and SandersBush, 1986), but this was not feasible in mice.

Our studies also suggest that changes in the proportion of edited isoforms alter the density of $5-\mathrm{HT}_{2 \mathrm{C}}$ receptor binding sites within the brain. VGV/Y mice, solely expressing the VGV isoform, have a 25 -fold increase in $5-\mathrm{HT}_{2 \mathrm{C}}$ receptor density relative to WT mice, similar to that found by Morabito et al. (2007). In heterozygous $\mathrm{VGV} / \mathrm{X}$ mice, the percentage of RNA isoform encoding VGV and the density of 5- $\mathrm{HT}_{2 \mathrm{C}}$ receptor binding sites is approximately halfway between WT and VGV/Y mice. This gene-dose dependent increase in binding site density supports the notion that the increases are not the result of erroneous genetic manipulation. In addition, receptor autoradiography suggests that the increased expression of 5- $\mathrm{HT}_{2 \mathrm{C}}$ 
receptor in VGV/Y mice does not reflect aberrant distribution of the receptor. It is possible that the increased density is a compensatory response to reduced cellular function of the edited receptor. In support of this conclusion, transgenic mice solely expressing the non-edited, highly functional, 5- $\mathrm{HT}_{2 \mathrm{C}-\mathrm{INI}}$ receptor have reduced receptor density (unpublished results).

The molecular mechanism of the substantial density alteration in mutant mice is unknown. In the initial characterization of the VGV/Y mouse phenotype, Morabito et al. (2007) found no change in the steady state levels of $5-\mathrm{HT}_{2 \mathrm{C}}$ receptor RNA transcripts was detected. Other possible mechanisms include differences in translation efficiency or stability of different protein isoforms. The latter is suggested by studies in cultured cells showing that the VGV isoform has diminished ability to bind to beta-arrestin and translocate into intracellular compartments (Marion et al., 2004). It is important to point out that the RNA isoform distribution, even in heterozygous mice where the VGV isoform accounts for approximately $50 \%$, is markedly different from the native situation where the VGV isoform represents less than $5 \%$. It is possible that some aberrant regulatory mechanism, which is not engaged under normal circumstances, is responsible for the marked increase in $5-\mathrm{HT}_{2 \mathrm{C}-\mathrm{VGV}}$ receptor density in the mutant mice. This question can only be definitively answered when a method becomes available for isolation and quantification of individual protein isoforms.

Although our pharmacological studies in brains of mice expressing the VGV isoform document reduced G-protein coupling capacity, the marked increase in $5-\mathrm{HT}_{2 \mathrm{C}}$ receptor site density may mitigate this diminished cellular signal in the intact animal. To investigate the functional consequences in vivo of these opposing effects, we employed a behavioral assay of $5-\mathrm{HT}_{2 \mathrm{C}}$ receptor activation. $5-\mathrm{HT}_{2 \mathrm{C}}$ receptor agonists, such as MK212, have long been known to induce hypolocomotion (Fone et al., 1998; Gleason and Shannon, 1998; Gleason et al., 2001; Stiedl et al., 2007), although there is debate about their specificity. Recent studies in $5-\mathrm{HT}_{2 \mathrm{C}}$ receptor knockout mice (Fletcher et al., 2009), showing that MK212-induced hypolocomotion is eliminated, suggest that, in mice, this behavior is a valid measure of in vivo $5-\mathrm{HT}_{2 \mathrm{C}}$ receptor activation. We found that MK212 elicits a dose-dependent decrease in locomotor activity in both WT and VGV/Y mice, but the sensitivity to MK212 is dramatically increased in VGV/Y mice. This observation confirms the work of Kawahara et al. (2008), and importantly shows that the marked behavioral sensitization is reproduced on another background strain. These data suggest that the large increase in receptor density overcomes the reduced G-protein coupling of the VGV receptor. The finding that $5-\mathrm{HT}_{2 \mathrm{C}}$ antagonists increase locomotor activity in VGV/Y mice (Kawahara et al., 2008; data not shown) agrees with this interpretation. Given emerging evidence suggesting that the $5-\mathrm{HT}_{2 \mathrm{C}}$ receptor attenuates $\mathrm{DA}$ release and $5-\mathrm{HT}_{2 \mathrm{C}}$ receptor antagonists augment the action of dopamine releasing agents such as cocaine (Filip and Cunningham, 2003; De Deurwaerdere et al.,

\section{REFERENCES}

Abramoff,M.D., Magelhaes, P.J., and Ram, S. J. (2004). Image processing with ImageJ. Biophotonics Int. 11, 36-42.

Alex, K. D., and Pehek, E. A. (2007). Pharmacologic mechanisms of serotonergic regulation of dopamine neurotransmission. Pharmacol. Ther. 113, 296-320.

Appel, N. M., Mitchell, W. M., Garlick, R. K., Glennon, R. A., Teitler, M., and De Souza, E. B. (1990). Autoradiographic characterization of (+-)-1-(2,5-dimethoxy-4-[125I]

2004; Navailles et al., 2004; Alex and Pehek, 2007), we examined DA turnover as another index of in vivo $5-\mathrm{HT}_{2 \mathrm{C}}$ receptor function. $5-\mathrm{HT}_{2 \mathrm{C}}$ receptor regulation of DA release is complex, involving direct and indirect pathways; microdialysis studies suggest that the mechanism of regulation differs in the nigrostriatal versus mesocorticolimbic DA systems (Di Matteo et al., 1999; Di Giovanni et al., 2000; see Di Matteo et al., 2008 for review). This may explain the regional difference seen in saline-treated VGV/Y mice, where DA turnover in the mutant mice is decreased in frontal cortex but not in striatum. Microdialysis experiments combined with direct microinjection would be valuable in pursuing this question. The finding that SB206553 increases DA turnover in frontal cortex and striatum of VGV/Y mice is consistent with the evidence that $5-\mathrm{HT}_{2 \mathrm{C}}$ receptors inhibit DA release in both areas. The ability of SB206553 to increase DA release has been proposed to reflect constitutive activity of the $5-\mathrm{HT}_{2 \mathrm{C}}$ receptor (De Deurwaerdere et al., 2004); however, such an explanation is less plausible in mice solely expressing the VGV isoform, since in vitro data in transfected cells shows that this isoform is essentially devoid of constitutive activity (Herrick-Davis et al., 1999; Niswender et al., 1999; Wang et al., 2000; Berg et al., 2008) and the present studies in brain are consistent with that interpretation. An alternative explanation is suggested by our finding of increased 5-HT turnover in VGV/Y mice given SB206553; enhanced release of 5-HT onto the up-regulated $5-\mathrm{HT}_{2 \mathrm{C}}$ receptors may play a role in the SB206553 modulation of DA release in VGV/Y mice.

In summary, in vitro studies in transfected cell lines have shown that RNA editing of 5- $\mathrm{HT}_{2 \mathrm{C}}$ receptor RNA transcripts profoundly alters the signaling properties of the $5-\mathrm{HT}_{2 \mathrm{C}}$ receptor protein. The current studies utilizing genetically modified mice solely expressing the most extensively edited isoform of the $5-\mathrm{HT}_{2 \mathrm{C}}$ receptor show, for the first time, that the G-protein coupling capacity in the brain is altered, i.e., expression of fully edited 5- $\mathrm{HT}_{2 \mathrm{C}-\mathrm{VGV}}$ receptor isoform within the brain blunts receptor:G-protein coupling. We further show that changes in the degree of editing significantly alters the density of receptor binding sites within the brain, suggesting that the pattern of protein isoforms, and hence the inferred overall function of the receptor protein, may not reflect the pattern of RNA isoforms. This conclusion points to a critical need for a method that differentiates $5-\mathrm{HT}_{2 \mathrm{C}}$ receptor protein isoforms in brain tissue. Until such a method becomes available, clinical and laboratory investigations must continue to rely on RNA isoform distribution to infer function. Our studies emphasize the need for caution in these interpretations.

\section{ACKNOWLEDGMENTS}

The authors acknowledge the technical assistance of Kathleen Patterson and Erin E. Watt. This work was supported by National Institute of Health training grants [T32 MH065782 (U.B.OD), T32 MH065215 (C.E.C.)]; National Institute of Health research grants [R01 MH34007 (E.S.B.), R21 MH77942 (D.C.A.), and P50 MH078028 (E.S.B., R.B.E.)].

iodophenyl)-2-aminopropane ([125I]DOI) binding to 5-HT2 and

5-HT1c receptors in rat brain. $J$.

Pharmacol. Exp. Ther. 255, 843-857.

Ballesteros, J., Kitanovic, S., Guarnieri, F.,

Davies, P., Fromme, B. J., Konvicka,

K., Chi, L., Millar, R. P., Davidson, J.
S., Weinstein, H., and Sealfon, S. C. (1998). Functional microdomains in G-protein-coupled receptors. The conserved arginine-cage motif in the gonadotropin-releasing hormone receptor. J. Biol. Chem. 273, 10445-10453. 
Berg, K. A., Harvey, J. A., Spampinato, U., and Clarke, W.P. (2008). Physiological and therapeutic relevance of constitutive activity of 5-HT 2A and 5-HT 2C receptors for the treatment of depression. Prog. Brain Res. 172, 287-305.

Buhot, M. C. (1997). Serotonin receptors in cognitive behaviors. Curr. Opin. Neurobiol. 7, 243-254.

Burns, C. M., Chu, H., Rueter, S. M., Hutchinson, L. K., Canton, H., Sanders-Bush, E., and Emeson, R. B. (1997). Regulation of serotonin-2C receptor G-protein coupling by RNA editing. Nature 387, 303-308.

Canal, C. E., Mahautmr, K. C., Cao, C., Sanders-Bush,E., and Airey,D.C. (2009). RNA editing of the serotonin $2 \mathrm{C}$ receptor and expression of Galpha protein: genetic mouse models do not support a role for regulation or compensation. J. Neurochem. 108, 1136-1142.

Conn, P. J., and Sanders-Bush, E. (1986). Agonist-induced phosphoinositide hydrolysis in choroid plexus. $J$. Neurochem. 47, 1754-1760.

De Deurwaerdere, P., Navailles, S., Berg, K. A., Clarke, W. P., and Spampinato, U. (2004). Constitutive activity of the serotonin2C receptor inhibits in vivo dopamine release in the rat striatum and nucleus accumbens. J. Neurosci. 24, 3235-3241.

Delgado, P. L., and Moreno, F. A. (1998). Hallucinogens, serotonin and obsessive-compulsive disorder. $J$. Psychoactive Drugs 30, 359-366.

Di Giovanni, G., Di Matteo, V., Di Mascio, M., and Esposito, E. (2000). Preferential modulation of mesolimbic vs. nigrostriatal dopaminergic function by serotonin $(2 \mathrm{C} / 2 \mathrm{~B})$ receptor agonists: a combined in vivo electrophysiological and microdialysis study. Synapse 35, 53-61.

DiMatteo, V., Di Giovanni, G., Di Mascio, M., and Esposito, E. (1999). SB 242084, a selective serotonin $2 \mathrm{C}$ receptor antagonist, increases dopaminergic transmission in the mesolimbic system. Neuropharmacology 38, 1195-1205.

Di Matteo, V., Di Giovanni, G., Pierucci, M., and Esposito, E. (2008). Serotonin control of central dopaminergic function: focus on in vivo microdialysis studies. Prog. Brain Res. 172, 7-44.

Dracheva, S., Chin, B., and Haroutunian, V. (2008a). Altered serotonin 2C receptor RNA splicing in suicide: association with editing. Neuroreport 19, 379-382.

Dracheva, S., Patel, N., Woo, D. A., Marcus, S. M., Siever, L. J., and Haroutunian, V. (2008b). Increased serotonin $2 \mathrm{C}$ receptor mRNA editing: a possible risk factor for suicide. Mol. Psychiatry 13, 1001-1010

Englander, M. T., Dulawa, S. C., Bhansali, P., and Schmauss, C. (2005). How stress and fluoxetine modulate serotonin
2C receptor pre-mRNA editing. $J$. Neurosci. 25, 648-651.

Filip, M., and Cunningham, K. A. (2003). Hyperlocomotive and discriminative stimulus effects of cocaine are under the control of serotonin (2C) (5-HT(2C)) receptors in rat prefrontal cortex. $J$. Pharmacol. Exp. Ther. 306, 734-743.

Fitzgerald, L. W., Iyer, G., Conklin, D. S., Krause, C. M., Marshall, A., Patterson, J.P., Tran, D.P., Jonak, G. J., and Hartig, P. R. (1999). Messenger RNA editing of the human serotonin 5-HT2C receptor. Neuropsychopharmacology 21(Suppl. 2), 82S-90S.

Flaisher-Grinberg, S., Klavir, O., and Joel, D. (2008). The role of 5-HT2A and 5 -HT2C receptors in the signal attenuation rat model of obsessive-compulsive disorder. Int. J. Neuropsychopharmacol. 11, 811-825.

Fletcher, P. J., Tampakeras, M., Sinyard, J., Slassi, A., Isaac, M., and Higgins, G. A. (2009). Characterizing the effects of 5-HT(2C) receptor ligands on motor activity and feeding behaviour in 5-HT(2C) receptor knockout mice. Neuropharmacology 57, 259-267.

Fone, K. C., Austin, R. H., Topham, I. A., Kennett, G.A., and Punhani, T. (1998). Effect of chronic m-CPP on locomotion, hypophagia, plasma corticosterone and 5-HT2C receptor levels in the rat. Br. J. Pharmacol. 123, 1707-1715.

Gaborik,Z., Jagadeesh, G.,Zhang, M.,Spat, A., Catt, K. J., and Hunyady, L. (2003). The role of a conserved region of the second intracellular loop in AT1 angiotensin receptor activation and signaling. Endocrinology 144, 2220-2228.

Giorgetti, M., and Tecott, L. H. (2004). Contributions of 5-HT(2C) receptors to multiple actions of central serotonin systems. Eur. J. Pharmacol. 488, 1-9.

Gleason,S.D.,Lucaites, V.L.,Shannon,H.E., Nelson, D. L., and Leander, J. D. (2001). $\mathrm{m}$-CPP hypolocomotion is selectively antagonized by compounds with high affinity for 5-HT(2C) receptors but not $5-\mathrm{HT}(2 \mathrm{~A})$ or $5-\mathrm{HT}(2 \mathrm{~B})$ receptors. Behav. Pharmacol. 12, 613-620.

Gleason, S.D., and Shannon, H.E. (1998). Meta-chlorophenylpiperazineinduced changes in locomotor activity are mediated by $5-\mathrm{HT} 1$ as well as $5-\mathrm{HT} 2 \mathrm{C}$ receptors in mice. Eur. J. Pharmacol. 341, 135-138.

Griebel, G. (1995). 5-Hydroxytryptami neinteracting drugs in animal models of anxiety disorders: more than 30 years of research. Pharmacol. Ther. 65, 319-395.

Gurevich, I., Tamir, H., Arango, V., Dwork, A. J., Mann, J. J., and Schmauss, C. (2002). Altered editing of serotonin $2 \mathrm{C}$ receptor pre-mRNA in the prefrontal cortex of depressed suicide victims. Neuron 34, 349-356.

Halford, J. C., Harrold, J. A., Boyland, E. J., Lawton, C. L., and Blundell,J.E. (2007). Serotonergic drugs: effects on appetite expression and use for the treatment of obesity. Drugs 67, 27-55.

Herrick-Davis, K., Grinde, E., and Niswender, C. M. (1999). Serotonin 5-HT2C receptor RNA editing alters receptor basal activity: implications for serotonergic signal transduction. J. Neurochem. 73, 1711-1717.

Iwamoto, K., Nakatani, N., Bundo, M., Yoshikawa, T., and Kato, T. (2005). Altered RNA editing of serotonin $2 \mathrm{C}$ receptor in a rat model of depression. Neurosci. Res. 53, 69-76.

Kawahara, Y., Grimberg, A., Teegarden, S., Mombereau, C., Liu, S., Bale, T. L., Blendy, J.A., and Nishikura, K. (2008). Dysregulated Editing of Serotonin $2 \mathrm{C}$ Receptor mRNAs Results in Energy Dissipation and Loss of Fat Mass. J. Neurosci. 28, 12834-12844.

Marion, S., Weiner,D.M., and Caron, M. G. (2004). RNA editing induces variation in desensitization and trafficking of 5-hydroxytryptamine $2 \mathrm{c}$ receptor isoforms. J. Biol. Chem. 279, 2945-2954.

Meltzer, H. Y., Li, Z., Kaneda, Y., and Ichikawa,J.(2003).Serotonin receptors: their key role in drugs to treat schizophrenia. Prog. Neuropsychopharmacol. Biol. Psychiatry 27, 1159-1172.

Millan, M. J. (2005). Serotonin 5-HT2C receptors as a target for the treatment of depressive and anxious states: focus on novel therapeutic strategies. Therapie 60, 441-460.

Milligan, G. (1993). Regional distribution and quantitative measurement of the phosphoinositidase C-linked guanine nucleotide binding proteins G11 alpha and Gq alpha in rat brain. J. Neurochem. 61, 845-851.

Morabito, M. V., Abbas, A., Jacobs, M. M., Kump, D. S., Resnick, J. L., Roth, B. L., Nagy, T. R., Kesterson, R. A., and Emeson, R. B. (2007). Mice solely expressing the fully edited isoform of the serotonin $2 \mathrm{C}$ receptor as an animal model of Prader-Willi Syndrome. Soc. Neurosci. Abstr. 37, 465.

Morabito, M. V., and Emeson, R. B. (2009). RNA editing as a therapeutic target for CNS disorders. Neuropsychopharmacology 34, 246.

Moro, O., Lameh, J., Hogger, P., and Sadee, W. (1993). Hydrophobic amino acid in the i2 loop plays a key role in receptor-G protein coupling. J. Biol. Chem. 268, 22273-22276.

Navailles, S., De Deurwaerdere, P., Porras, G., and Spampinato, U. (2004). In vivo evidence that 5 -HT2C receptor antagonist but not agonist modulates cocaine-induced dopamine outflow in the rat nucleus accumbens and striatum. Neuropsychopharmacology 29, 319-326.

Niswender, C. M., Copeland, S. C., Herrick-Davis, K., Emeson, R. B., and Sanders-Bush, E. (1999). RNA editing of the human serotonin 5-hydrox- ytryptamine $2 \mathrm{C}$ receptor silences constitutive activity. J. Biol. Chem. 274, 9472-9478.

Niswender,C.M.,Herrick-Davis,K.,Dilley, G. E., Meltzer, H. Y., Overholser, J. C., Stockmeier, C. A., Emeson, R. B., and Sanders-Bush, E. (2001). RNA editing of the human serotonin 5-HT2C receptor. alterations in suicide and implications for serotonergic pharmacotherapy. Neuropsychopharmacology 24, 478-491.

Olivier, B., van Oorschot, R., and Waldinger, M. D. (1998). Serotonin serotonergic receptors, selective serotonin reuptake inhibitors and sexual behaviour. Int. Clin. Psychopharmacol. 13(Suppl. 6), S9-S14.

Samama, P., Cotecchia, S., Costa, T., and Lefkowitz, R. J. (1993). A mutationinduced activated state of the beta 2 -adrenergic receptor. Extending the ternary complex model. J. Biol. Chem. 268, 4625-4636.

Serretti, A., Artioli, P., and De Ronchi, D. (2004). The 5-HT2C receptor as a target for mood disorders. Expert. Opin. Ther. Targets 8, 15-23.

Stiedl, O., Misane, I., Koch, M., Pattij, T., Meyer, M., and Ogren, S. O. (2007). Activation of the brain 5-HT2C receptors causes hypolocomotion without anxiogenic-like cardiovascular adjustments in mice. Neuropharmacology 52 , 949-957.

Wang, Q., O’Brien, P. J., Chen, C. X., Cho, D. S., Murray, J. M., and Nishikura, K. (2000). Altered G protein-coupling functions of RNA editing isoform and splicing variant serotonin $2 \mathrm{C}$ receptors. J. Neurochem. 74, 1290-1300.

Conflict of Interest Statement: The authors declare that the research was conducted in the absence of any commercial or financial relationships that could be construed as a potential conflict of interest.

Received: 12 October 2009; paper pending published: 27 October 2009; accepted: 20 January 2010; published online: 16 March 2010.

Citation: Olaghere da Silva UB, Morabito $M V$, Canal CE, Airey DC, Emeson RB and Sanders-Bush E (2010) Impact of RNA editing on functions of the serotonin $2 \mathrm{C}$ receptor in vivo. Front. Neurosci. 4:26. doi: 10.3389/neuro.23.001.2010

This article was submitted to Frontiers in Neuropharmacology, a specialty of Frontiers in Neuroscience.

Copyright $\odot 2010$ Olaghere da Silva, Morabito, Canal, Airey, Emeson and Sanders-Bush. This is an open-access article subject to an exclusive license agreement between the authors and the Frontiers Research Foundation, which permits unrestricted use, distribution, and reproduction in any medium, provided the original authors and source are credited. 